\title{
REVIEW
}

\section{Epigenetics of renal cell carcinoma: the path towards new diagnostics and therapeutics}

\author{
Mark R Morris, ${ }^{1,2}$ and Eamonn R Maher ${ }^{1,2,3 *}$
}

\begin{abstract}
Aberrant DNA methylation, in particular promoter hypermethylation and transcriptional silencing of tumor suppressor genes, has an important role in the development of many human cancers, including renal cell carcinoma (RCC). Indeed, apart from mutations in the well studied von Hippel-Lindau gene (VHL), the mutation frequency rates of known tumor suppressor genes in RCC are generally low, but the number of genes found to show frequent inactivation by promoter methylation in RCC continues to grow. Here, we review the genes identified as epigenetically silenced in RCC and their relationship to pathways of tumor development. Increased understanding of RCC epigenetics provides new insights into the molecular pathogenesis of RCC and opportunities for developing novel strategies for the diagnosis, prognosis and management of RCC.
\end{abstract}

\section{Background}

Epidemiology and pathogenesis of renal cell carcinoma Kidney cancers account for about $2 \%$ of all cancers, and more than 200,000 new cases of kidney cancer are diagnosed worldwide each year [1]. The most common form of kidney cancer in adults is renal cell carcinoma (RCC). Most RCC cases (approximately 75\%) are classified as clear cell (conventional) RCC (ccRCC), and the next most frequent subtype is papillary RCC (pRCC; approximately $15 \%$ of all cases) [2]. The most common genetic event in the evolution of sporadic ccRCC is inactivation of the von Hippel-Lindau $(V H L)$ tumor suppressor gene (TSG) [3-6]. VHL inactivation leads to stabilization of the hypoxia-inducible transcription factors HIF-1 and HIF-2

\footnotetext{
*Correspondence: e.r.maher@bham.ac.uk

'Renal Molecular Oncology Group, Medical and Molecular Genetics, School of Clinical and Experimental Medicine, College of Medical and Dental Sciences, University of Birmingham, Birmingham B15 2TT, UK

Full list of author information is available at the end of the article
}

and activation of a wide repertoire of hypoxia response genes [7]. The frequency of $V H L$ mutations in sporadic ccRCC has been reported to be as high as 75\% (although $V H L$ mutations are rare in non-clear-cell forms of RCC). In addition to VHL mutations, VHL allele loss of 3p25, resulting in biallelic $V H L$ inactivation, is the most frequent copy number abnormality in ccRCC (as predicted by a classical 'two hit' model of tumorigenesis, where loss of the second allele of a key tumour suppressor is required for tumour formation to occur) [8,9].

Although the $V H L$ mutations in primary RCC were detected about 16 years ago, attempts to identify other frequently mutated RCC genes have been unsuccessful, with none of the thousands of genes tested so far mutated in over 15\% of tumors [10]. TSG inactivation may result from genetic or epigenetic events, and it is well recognized that epigenetic silencing of TSGs has a significant role in the pathogenesis of many, if not all, human cancers. Indeed, promoter methylation and epigenetic silencing of $V H L$ in RCC [5] was one of the first examples of this phenomenon and so far approximately 60 genes have been suggested to be epigenetically dysregulated in RCC (Table 1).

\section{Epigenetics and cancer}

There are two major, interrelated modes of epigenetic regulation in the mammalian genome: cytosine methylation and histone modification. Only cytosine bases located 5 ' to a guanosine can be methylated, and CpG dinucleotides are generally underrepresented in the genome. However, short regions found frequently in proximal promoter regions are $\mathrm{CpG}$ rich [11]. These regions (CpG islands, 0.4 to $4 \mathrm{~kb}$ long and found in over $50 \%$ of all genes) are generally unmethylated in normal cells but may be hypermethylated in tumors, where CpG island methylation is also associated with histone modification and chromatin remodeling resulting in transcriptional silencing [12-16]. Epigenetic states are, like gene mutations, inherited in cell division but, unlike mutations, DNA methylation and other epigenetic changes are potentially reversible $[17,18]$.

In a non-disease setting, gene silencing by promoter methylation occurs to regulate the expression of germline 
Table 1. Gene methylation frequencies in RCC

\begin{tabular}{|c|c|c|c|c|c|c|c|c|}
\hline Gene & Locus & $\begin{array}{c}\text { Mean RCC } \\
\text { methylation } \\
(\%)\end{array}$ & $\begin{array}{l}\text { Number of } \\
\text { tumors } \\
\text { analyzed }\end{array}$ & $\begin{array}{c}\text { Range across } \\
\text { multiple } \\
\text { studies (\%) }\end{array}$ & ccRCC (\%) & pRCC (\%) & $\begin{array}{c}\text { Adj normal } \\
\text { methylation* } \\
\%(n)\end{array}$ & References \\
\hline APAF1 & $12 q 23$ & 98 & 170 & $97-100$ & 98 & - & $9(80)$ & {$[106,107]$} \\
\hline$A P C$ & $5 q 21-22$ & 17 & 253 & $14-29$ & 16 & 32 & 7 (72) & {$[34,40-43]$} \\
\hline BNCl & $15 q 25$ & 46 & 59 & - & - & - & $5(20)$ & [63] \\
\hline BTG3 & $21 \mathrm{q} 11.2-21.1$ & 70 & 20 & - & - & - & $0(20)$ & [108] \\
\hline CASP8 & $2 q 33-34$ & 6 & 139 & $0-16$ & 0 & - & - & {$[53,107]$} \\
\hline $\mathrm{CDH} 1$ & $16 q 22.1$ & 35 & 229 & $11-80$ & 83 & 69 & $87(62)$ & {$[33,41-43,53]$} \\
\hline $\mathrm{CDH} 13$ & $16 q 24.2-24.3$ & 3 & 40 & - & - & - & - & [53] \\
\hline COL14A1 & $8 q 24$ & 44 & 41 & - & - & - & $5(20)$ & [63] \\
\hline COL15A1 & $9 q 22$ & 53 & 65 & - & - & - & $30(30)$ & [63] \\
\hline COLIA1 & $17 q 21.31-22$ & 57 & 30 & - & 65 & 40 & - & [106] \\
\hline CRBP1 & $3 q 21-22$ & 9 & 22 & - & - & - & - & [54] \\
\hline CST6 & $11 q 13$ & 46 & 61 & - & - & - & $11(35)$ & [63] \\
\hline CXCL16 & 17p13.2 & 42 & 62 & - & 43 & 40 & $43(21)$ & [109] \\
\hline$D A L-1 / 4.1 B$ & $18 p 11.3$ & 45 & 55 & - & 45 & - & - & [110] \\
\hline DAPK1 & $9 q 34.1$ & 35 & 219 & $24-41$ & 38 & - & - & {$[54,108,111]$} \\
\hline DKK1 & $10 q 11.2$ & 44 & 62 & $0-52$ & 44 & - & $8(62)$ & {$[63,65]$} \\
\hline DKK2 & $4 q 25$ & 58 & 52 & - & 58 & - & $6(52)$ & [64] \\
\hline DKK3 & 11p15.2 & 50 & 62 & - & 53 & - & $16(62)$ & [62] \\
\hline DLC1 & $8 p 22-21.3$ & 35 & 34 & - & - & - & $3(34)$ & [112] \\
\hline ESR1 & $6 q 25.1$ & 69 & 65 & - & 67 & 77 & $77(62)$ & [43] \\
\hline ESR2 & $14 q 23.2$ & 53 & 65 & - & 56 & 46 & $43(62)$ & [43] \\
\hline FHIT & $3 p 14.2$ & 53 & 87 & $52-53$ & 53 & 54 & $52(0-69)(82)$ & {$[43,53]$} \\
\hline FLCN & $17 p 11.2$ & 9 & 120 & $0-33$ & 21 & - & - & [113-115] \\
\hline GREM1 & $15 q 13$ & 24 & 165 & $20-41$ & 20 & - & $15(79)$ & {$[63,101]$} \\
\hline GSTP1 & $11 q 13$ & 10 & 177 & $8-12$ & 6 & 15 & $0(72)$ & {$[33,42,43]$} \\
\hline HOXB13 & $17 q 21.2$ & 30 & 50 & - & - & - & 0 & [102] \\
\hline$|G F B P|$ & 7p14-12 & 30 & 30 & - & 35 & 20 & - & [106] \\
\hline IGFBP3 & 7p14-12 & 12 & 120 & $3-37$ & 13 & 40 & - & {$[108,116]$} \\
\hline$J U P$ & $17 q 21$ & 91 & 54 & - & - & 11 & $11(54)$ & [100] \\
\hline KTN19 & $17 q 21.2$ & 38 & 66 & - & 39 & 33 & $14(22)$ & [109] \\
\hline LOXL1 & $15 q 24$ & 35 & 23 & - & - & - & $24(17)$ & [63] \\
\hline LSAMP & $3 q 13.2-21$ & 26 & 53 & - & 26 & - & - & [67] \\
\hline MDRI & $7 q 21.1$ & 86 & 65 & - & 87 & 85 & $97(62)$ & [43] \\
\hline MGMT & $10 q 26$ & 8 & 225 & $2-33$ & 2 & 0 & $0(62)$ & {$[33,41-43,54]$} \\
\hline MT1G & $16 q 13$ & 20 & 25 & - & - & - & - & [54] \\
\hline p14ARF & $9 p 21$ & 33 & 299 & $17-68$ & 36 & 40 & 20 & {$[33,34,40,43]$} \\
\hline p16INK4 & $9 p 21$ & 11 & 407 & $0-80$ & 10 & 13 & $0(87)$ & $\begin{array}{c}{[34,35} \\
40-43,54,81]\end{array}$ \\
\hline PDLIM4 & $5 q 31$ & 43 & 41 & - & - & - & $0(22)$ & [63] \\
\hline$P M L$ & $15 q 22$ & 3 & 90 & - & 3 & - & - & [107] \\
\hline PTGS2 & $1 \mathrm{q} 25.2-25.3$ & 95 & 65 & - & 96 & 92 & $100(62)$ & [43] \\
\hline RARB & $3 p 24$ & 13 & 206 & $0-53$ & 2 & 0 & $0(77)$ & {$[34,41-43,54]$} \\
\hline RASSF1 & $3 p 21.3$ & 51 & 735 & $28-91$ & 59 & 75 & $48(0-100)(174)$ & $\begin{array}{c}{[34,35,38,} \\
40-46]\end{array}$ \\
\hline RASSF5 & $1 q 32.1$ & 28 & 79 & $19-32$ & - & - & - & {$[54,67]$} \\
\hline$R O B O 1$ & $3 p 12$ & 18 & 44 & - & 18 & - & - & [117] \\
\hline RPRM & $2 q 23$ & 44 & 52 & - & - & - & $18(44)$ & [63] \\
\hline$S D H B$ & 1p36.1-35 & 4 & 25 & - & - & - & - & [53] \\
\hline SFRP1 & $8 p 12-11.1$ & 47 & 234 & $34-80$ & 50 & 18 & $5(152)$ & [59-63] \\
\hline SFRP2 & $4 q 31.3$ & 53 & 62 & - & 56 & - & $10(62)$ & [62] \\
\hline
\end{tabular}


Table 1. Continued

\begin{tabular}{|c|c|c|c|c|c|c|c|c|}
\hline Gene & Locus & $\begin{array}{c}\text { Mean RCC } \\
\text { methylation } \\
(\%)\end{array}$ & $\begin{array}{l}\text { Number of } \\
\text { tumors } \\
\text { analyzed }\end{array}$ & $\begin{array}{c}\text { Range across } \\
\text { multiple } \\
\text { studies (\%) }\end{array}$ & ccRCC (\%) & pRCC (\%) & $\begin{array}{c}\text { Adj normal } \\
\text { methylation* } \\
\%(n)\end{array}$ & References \\
\hline SFRP4 & 7p14-13 & 53 & 62 & - & 56 & - & $15(62)$ & {$[62]$} \\
\hline SFRP5 & 10q24.1 & 57 & 62 & - & 59 & - & $15(62)$ & [62] \\
\hline SLIT2 & $4 q 15.2$ & 25 & 48 & - & - & - & $8(12)$ & [118] \\
\hline SPINT2 & $19 q 13.2$ & 38 & 118 & - & 30 & 45 & $5(38)$ & [70] \\
\hline TIMP3 & $22 q 12.1-13.2$ & 51 & 289 & $20-78$ & 36 & 32 & $14(104)$ & {$[34,40-43,119]$} \\
\hline TU3A & $3 p 21.1$ & 39 & 61 & - & 42 & 25 & $0(24)$ & [49] \\
\hline UCHLI & $4 p 14$ & 38 & 32 & - & - & - & $0(32)$ & [116] \\
\hline VHL & $3 p 26-25$ & 16 & 740 & $8-31$ & 14 & 16 & 0 & {$[5,9,33-36,40]$} \\
\hline WIF1 & $12 q 14.3$ & 73 & 62 & - & 76 & & $23(62)$ & [62] \\
\hline XAF1 & $17 p 13.2$ & 12 & 84 & $8-50$ & - & - & $0(4)$ & {$[120,121]$} \\
\hline
\end{tabular}

*Where the range of methylation in adjacent (Adj) normal tissue is high across multiple studies, this range is indicated in parentheses before the number analyzed. Abbreviations: APAF1, apoptotic protease activating factor 1; APC, adenomatous polyposis coli; BNC1, basonuclin 1; BTG3, B-cell translocation gene 3; CASP8, caspase 8; $C D H 1$, cadherin 1; $C D H 13$, cadherin 13; COL, collagen; CRBP, retinol binding protein 1, cellular; CST6, cystatin E/M; CXCL, chemokine (C-X-C motif) ligand; DAL, differentially expressed in adenocarcinoma of the lung; DAPK, death-associated protein kinase; DKK, dickkopf; DLC, deleted in liver cancer; ESR, estrogen receptor; FHIT, fragile histidine triad; FLCN, folliculin; GREM, gremlin; GSTP, glutathione s-transferase protein; HOXB, homeobox family B; IGFBP, insulin-like growth factor binding protein; JUP, junction plakoglobin (also called $\gamma$-catenin); KTN, keratin; LOXL, lysyl oxidase-like; LSAMP, limbic system-associated membrane protein; MDRI, multiple drug resistance gene; MGMT, 0-6-methylguanine-DNA methyltransferase; MT1G, metallothionein 1G; $14 A R F$, cyclin-dependent kinase inhibitor $2 A$ alternative reading frame; p16INK4, cyclindependent kinase inhibitor 2A; PDLIM4, pdz and lim domain protein 4; PML, promyelocytic leukemia; PTGS, prostaglandin-endoperoxide synthase; RARB, retinoic acid receptor beta; RASSF, RAS association domain family; ROBO, roundabout; RPRM, reprimo; SDHB, Succinate dehydrogenase B; SFRP, secreted frizzled related protein; SLIT2, slit homolog 2; SPINT2, serine peptidase inhibitor, Kunitz type, 2; TIMP, Tissue inhibitor of metalloproteases; UCHL, ubiquitin carboxyl-terminal esterase L1; VHL, von Hippel-Lindau tumor suppressor; WIF, Wnt inhibitory factor; XAF, XIAP associated factor.

and tissue-specific genes and to regulate the monoallelic expression of imprinted genes [19-22]. However, in the past decade it has become accepted that aberrant promoter methylation and the resultant gene silencing can provide a selective advantage to neoplastic cells in the same manner that mutations do [22-26]. Thus, epigenetic silencing of 'gatekeeper' or 'caretaker' TSGs can occur frequently at the earliest stages of cancer initiation, resulting in the clonal evolution of a population of cells at risk of obtaining further genetic or epigenetic lesions $[27,28]$. In inherited cancer syndromes such as von HippelLindau disease (associated with susceptibility to RCC) de novo $V H L$ promoter hypermethylation can provide the 'second hit' that initiates tumor development [29]. In such cases methylation is specific to the wild-type allele, suggesting clonal selection for the epigenetic loss of expression.

\section{A survey of methylated genes in RCC}

In order to catalog candidate TSGs reported to show tumor-specific region hypermethylation in RCC, we searched PubMed and other online databases (such as PubMeth) [30]. Of the 58 genes that were identified as being methylated in RCC (Table 1, Figure 1; see Table 1 for full gene names), 43 had a mean combined methylation/ mutation rate of over $20 \%$ and the characteristics of these genes were analyzed in further detail (although 31 genes had been reported only by a single study).

\section{Chromosome 3p tumor suppressors}

Deletions of $3 p$ are frequent in many adult cancers [31] and occur in 45 to $90 \%$ of sporadic RCCs $[4,32,33]$.
Inactivation of the 3p25 TSG VHL is of critical importance to the pathogenesis of ccRCC and occurs in up to $86 \%$ of tumors [34]. Although $V H L$ mutations are rare in non-clear-cell RCC, $V H L$ methylation has been reported in pRCC and ccRCC $[9,35,36]$. VHL methylation does not associate with tumor stage, consistent with the interpretation that it is an early event in tumor formation [9,37]. In addition to $V H L$, several other $3 p$ candidate TSGs have been reported to be methylated in RCC (Figure 1). The RASSF1 gene maps to 3p21, a region of frequent allele loss in RCC and other cancers (including lung, bladder, breast and hepatocellular). Somatic RASSF1A mutations are infrequent in cancer [38], but RASSF1 is frequently methylated in sporadic RCC (and various other common cancers), either biallelically or as a second hit following $3 p$ deletion [39,40]. After $V H L$, RASSF1 methylation has been examined more than any other gene in sporadic RCC, the mean methylation frequency is $51 \%[34,35,38,41-47]$. In a study by Costa $e t$ al. [44], frequent RASSF1A methylation was detected in kidney tissue surrounding the excised tumor. Aberrant methylation in morphologically normal renal tissue adjacent to the tumor (but not in more distant normal tissue) has been interpreted as evidence that the TSG methylation is part of a 'field effect' at an early stage of tumorigenesis that produces a large number of cells with an initial epigenetic lesion that is then followed by additional genetic and/or epigenetic events that lead to tumor development. The candidate tumor suppressor gene TU3A (located at $3 \mathrm{p} 21.1$ ) is frequently downregulated in cancers, most notably prostate cancer [48] 


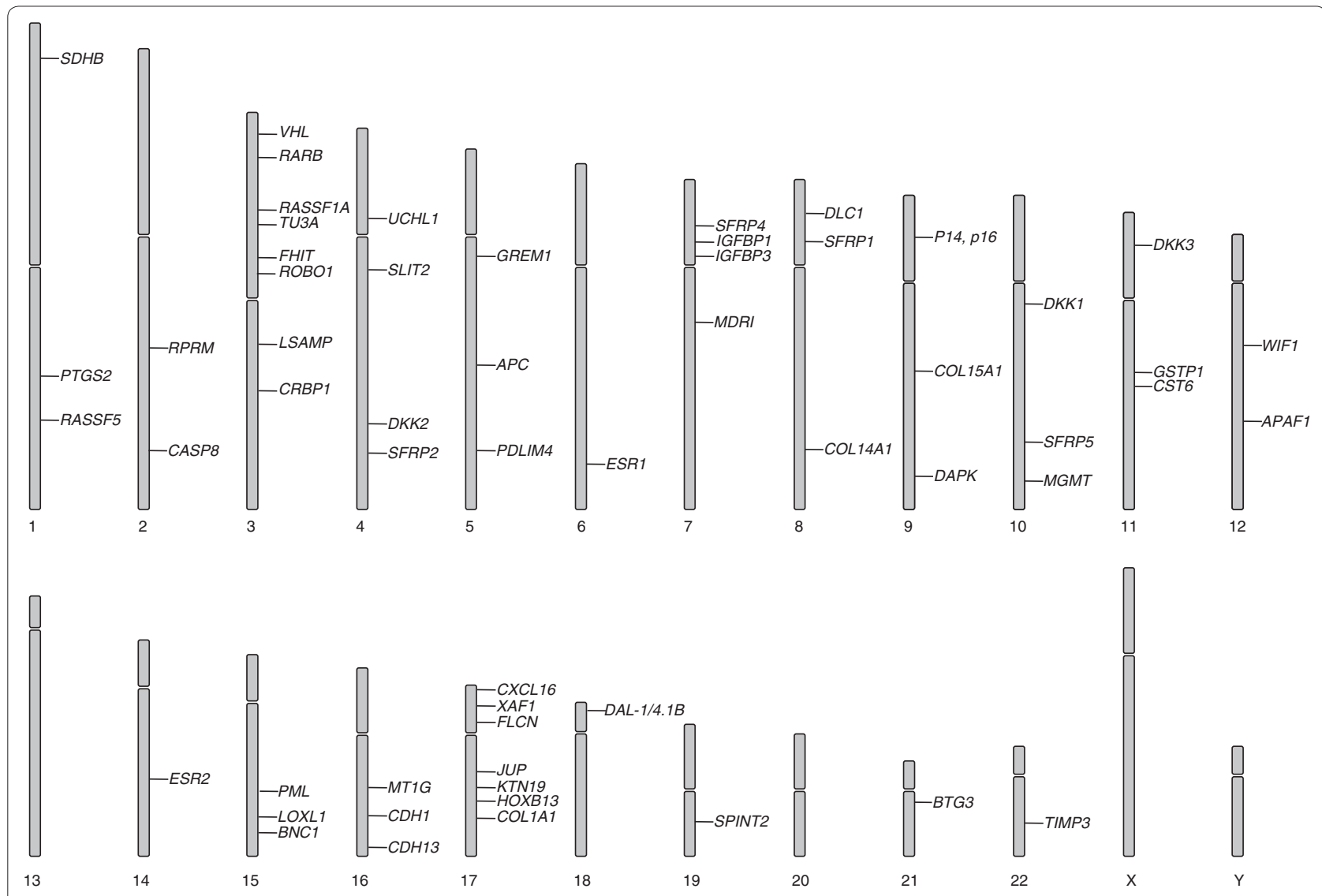

Figure 1. Genes methylated in RCC are distributed across the genome. However, there is a concentration of silenced genes at $3 p$ (see text for details). Methylated genes are also concentrated at chromosome 17 and both loss and gain of chromosome 17 have been reported in RCC.

and astrocytoma [49]. In one study of 61 tumors, TU3A was methylated in $42 \%$ of ccRCC and $25 \%$ of pRCC [50].

The FHIT gene encodes a diadenosine 5,5"'-P1,P3triphosphate hydrolase involved in purine metabolism. The gene encompasses the common fragile site FRA3B at 3p14. Loss of FHIT is common to many tumor types [51,52]. In vivo, re-expression of FHIT has tumor suppressing activity [53]. FHIT promoter methylation is common (52 to 53\%) in both ccRCC and pRCC [44,54].

$R A R B$ regulates cell proliferation and differentiation and, in common with other 3p TSGs (RARB maps to $3 \mathrm{p} 24$ ), is frequently downregulated or lost in multiple tumor types. However, several small studies have found $R A R B$ to be methylated in less than $20 \%$ of RCC cases $[35,42,44,55]$.

\section{WNT pathway regulators}

Dysregulation of the $\mathrm{WNT} / \beta$-catenin pathway is common in a variety of cancers, and oncogenic activation of this pathway drives the expression of genes that contribute to proliferation, survival and invasion [56,57]. Inhibitors of WNT signaling can be divided into two functional classes: the SFRP proteins, which bind directly to WNT, preventing its binding to the FZ receptor [58], and the Dickkopf (DKK) proteins, which bind to the Low-density lipoprotein receptor-related protein 5 (LRP5)-LRP6 component of the Wnt receptor complex [59]. The SFRP1, SFRP2, SFRP4, SFRP5 and related WIF1 genes are all frequently methylated in RCC (47 to 73\%) [60-64], as are the Dickkopf genes $D K K 1, D K K 2$ and $D K K 3$ (44 to 58\%) [63-66]. Recently, SFRP1 was shown to be overexpressed in metastatic RCC compared with nonmetastatic tumors, in which expression was often attenuated by promoter methylation [67].

\section{Epigenetics and familial RCC genes}

As described above, germline $V H L$ mutations cause inherited RCC and VHL inactivation is also critical to the development of most ccRCC. Similarly, a constitutional translocation associated with RCC susceptibility disrupted the NORE1A (RASSF5) and $L S A M P 1$ genes, and both genes were epigenetically inactivated in sporadic RCC [68]. However, somatic inactivation (by mutation or methylation) of other genes associated with inherited kidney cancer, such as FLCN, $F H$ and $S D H B$, is infrequent or absent (Table 1). 
Table 2. Technologies to identify genome-wide epigenetically regulated genes

\begin{tabular}{|c|c|c|c|}
\hline Method & Key features & Advantages & Disadvantages \\
\hline Functional epigenomics & $\begin{array}{l}\text { Methylated genes are re-expressed in } \\
\text { cell lines by treatment with } 5 \text {-aza-2'- } \\
\text { deoxycytidine. Expression arrays determine } \\
\text { reactivated genes }\end{array}$ & $\begin{array}{l}\text { Links hypermethylated sites to } \\
\text { gene silencing }\end{array}$ & $\begin{array}{l}\text { Correlating correct methylated site to } \\
\text { expression regulation is laborious. Cell } \\
\text { lines are frequently more methylated } \\
\text { than the corresponding tumors. }\end{array}$ \\
\hline $\begin{array}{l}\text { Methylation-dependent } \\
\text { immunoprecipitation (MeDIP) }\end{array}$ & $\begin{array}{l}\text { Methylated DNA is separated } \\
\text { from unmethylated DNA by } \\
\text { immunoprecipitation and hybridized to a } \\
\text { CpG island microarray }\end{array}$ & $\begin{array}{l}\text { Global analysis; produces } \\
\text { quantifiable results }\end{array}$ & $\begin{array}{l}\text { Dependent on good } \\
\text { immunoprecipitation efficiency; difficult } \\
\text { to determine the extent of methylation } \\
\text { across a specific } C p G \text { island }\end{array}$ \\
\hline Bead chip'Infinium' & $\begin{array}{l}\text { Bisulfite-modified DNA is hybridized to } \\
\text { beads containing DNA oligonucleotides } \\
\text { specific to CpG dinucleotide methylation. } \\
\text { Single base extension determines } \\
\text { methylation state }\end{array}$ & $\begin{array}{l}\text { Global analysis at single } \mathrm{CpG} \\
\text { sites using targeted probes; } \\
\text { quantitative data }\end{array}$ & $\begin{array}{l}\text { Provides data for only one or two CpG } \\
\text { dinucleotides per island; further work } \\
\text { may be required to determine the extent } \\
\text { of methylation at specific sites }\end{array}$ \\
\hline Next-generation sequencing & $\begin{array}{l}\text { Combines isolation of methylated DNA } \\
\text { using techniques such as MeDIP or } \\
\text { restriction digest and high-throughput } \\
\text { sequencing. Bisulfite-modified DNA can } \\
\text { also be sequenced directly }\end{array}$ & $\begin{array}{l}\text { Statistically robust; high } \\
\text { coverage; single nucleotide } \\
\text { resolution }\end{array}$ & $\begin{array}{l}\text { Initial set-up costs high; probe design can } \\
\text { be challenging }\end{array}$ \\
\hline
\end{tabular}

Nevertheless, SPINT2 (HAI2), which encodes a secreted inhibitor of MET activity (activating mutations in the $M E T$ proto-oncogene are associated with familial pRCC, although somatic mutations are infrequent in sporadic pRCC $[69,70])$, was found to be methylated in $30 \%$ of ccRCC and $45 \%$ of pRCC [71]. This observation demonstrates how TSG methylation can target familial RCC gene pathways. We note that several other epigenetically inactivated candidate TSGs, including members of the Wnt regulatory pathway [72], p16INK4a [73], CASP8 [74], GREM1 [75], RPRM [76], collagens [77], IGFBP1 [78], IGFBP3 [79] and PTGS2 [80], can be related to VHL-regulated pathways. However, genes involved in many other cellular processes have also been found to be epigenetically silenced in RCC (Table 1).

\section{Identification of novel RCC TSGs by epigenetic analyses}

Compared with the results of high-throughput sequencing studies of RCC [81], it seems that epigenetic studies have provided a much higher number of frequently inactivated candidate TSGs. Nevertheless, a combination of sequencing and epigenetic analysis provides the optimum strategy. Thus, although RASSF1A would not have been identified as an important RCC TSG by sequencing analysis alone, CDKN2A (which is mutated in approximately $10 \%$ of RCC and is the second most highly mutated gene in RCC [10]), is, on average, methylated in $11 \%$ of RCC $[35,36,41,43,44,55,82]$, yielding a combined inactivation rate of about $21 \%$. A wide variety of methodological approaches can be used to determine the promoter methylation status of candidate RCC TSGs and these have differing advantages and drawbacks (Tables 2 and 3 ). In addition to the detection of pathological promoter region methylation, it is important to demonstrate that this is associated with transcriptional silencing of the candidate TSG.

The functional epigenomics strategy uses 5-aza-2'deoxycytidine treatment of cancer cell lines to identify genes whose expression is reactivated following demethylation. Although this strategy can provide an unbiased approach to identifying candidate epigenetically inactivated TSGs, only a minority of the re-expressed genes are ultimately proven to be silenced in primary tumors. Some techniques, such as methylation-specific PCR, can be very sensitive, and it is reassuring when results are available from a large number of tumors and multiple studies because the frequencies of methylation for individual genes can show considerable variation (Table 1). Such variation can reflect differences between cohorts of tumor samples or methylation detection methodologies, and only in a minority of cases are there data available from multiple studies and over 100 tumor samples. For less well studied genes the evidence for pathogenicity is strengthened by reports of frequent tumor-specific methylation (or mutations) in other tumor types; this is the case for BNC1 [83], PDLIM4 [84,85], CST6 [86,87] SLIT2 [88,89], IGFBP3 [90,91] and SPINT2 [92-94].

So far, epigenetic studies in RCC have concentrated on the methylation of $\mathrm{CpG}$ islands at or near to gene promoters. Recent studies in colorectal cancer have indicated that methylation extends well beyond discrete islands. Indeed, approximately $50 \%$ of these ' $\mathrm{CpG}$ island shores' were found more than $2 \mathrm{~kb}$ from the nearest annotated gene [95]. As with CpG island methylation, CpG shore methylation inversely correlates with gene expression. Further investigation of global genomic 
Table 3. Technologies to analyze specific methylated regions

\begin{tabular}{|c|c|c|c|}
\hline Method & Key features & Advantages & Disadvantages \\
\hline Methylation-specific PCR (MSP) & $\begin{array}{l}\text { DNA primers are designed to distinguish } \\
\text { between methylated or un-methylated } \\
\text { DNA. Bisulfite-modified DNA is amplified }\end{array}$ & $\begin{array}{l}\text { Very sensitive; will identify very } \\
\text { low levels of methylated DNA in } \\
\text { a sample }\end{array}$ & $\begin{array}{l}\text { Very sensitive; easily contaminated; } \\
\text { requires further analysis to determine } \\
\text { level of methylation present }\end{array}$ \\
\hline $\begin{array}{l}\text { Combined bisulfite restriction } \\
\text { analysis (COBRA) }\end{array}$ & $\begin{array}{l}\text { Bisulfite-modified DNA is amplified using } \\
\text { non-discriminatory primers. PCR product is } \\
\text { digested with restriction enzymes that are } \\
\text { specific to methylated DNA sequences }\end{array}$ & $\begin{array}{l}\text { Robust detection of } \\
\text { methylation; not prone to false } \\
\text { positive results }\end{array}$ & $\begin{array}{l}\text { Does not give detailed analysis of region } \\
\text { amplified; requires complete bisulfite } \\
\text { conversion to prevent PCR bias }\end{array}$ \\
\hline Bisulfite sequencing & $\begin{array}{l}\text { Bisulfite-modified DNA is amplified using } \\
\text { non-discriminatory primers. PCR product is } \\
\text { cloned and sequenced }\end{array}$ & $\begin{array}{l}\text { Informative for all CpGs within } \\
\text { the region; provides allele- } \\
\text { specific methylation information }\end{array}$ & Laborious \\
\hline Pyro-sequencing & $\begin{array}{l}\text { Bisulfite-modified DNA is amplified } \\
\text { using non-discriminatory primers and } \\
\text { sequenced using pyro-sequencing } \\
\text { technology }\end{array}$ & $\begin{array}{l}\text { Multiple samples can be } \\
\text { analyzed in parallel; quantitative }\end{array}$ & Analysis is restricted by small read sizes \\
\hline
\end{tabular}

methylation patterns is necessary to elucidate the full role of epigenetic gene silencing (and oncogene activation) in RCC development. It is now accepted that in certain tumor types, colorectal being the best described, a subset of tumors show a CpG island methylator phenotype $\left(\mathrm{CIMP}^{+}\right)$, which associates with specific lesions such as BRAF mutations and microsatellite instability [96]. However, the relevance of the $\mathrm{CIMP}^{+}$phenotype to RCC has not yet been clearly defined [97]. The role of abnormal histone modification as an epigenetic factor in RCC development also remains to be investigated in depth. However, recent large-scale sequencing screens of RCC revealed mutations in the histone-modifying genes ubiquitously transcribed tetratricopeptide repeat gene on $x$ chromosome (UTX), set domain-containing protein 2 (SETD2) and lysinespecific demethylase 5C (KDM5C, JARID1C), and that loss of these genes correlated with transcriptional deregulation $[81,98]$. The interplay between erroneous histone modification and aberrant DNA methylation in the evolution of RCC merits further investigation.

\section{Translational medicine and RCC epigenetics Epigenetic biomarkers}

Methylated TSGs provide attractive options for biomarkers for the detection and prognosis prediction of cancers, including RCC [99]. DNA-based assays are often more robust than RNA-based assays, and whereas the mutation spectrum causing TSG inactivation is usually diverse (which limits the utility of mutation-specific detection strategies for tumor screening programs), TSG inactivation by promoter hypermethylation provides a more homogeneous target for molecular screening strategies. So far, large-scale gene sequencing studies have demonstrated that, with the exception of $V H L$, there are no genes that are mutated very frequently, but a significant number of genes do show frequent tumorspecific methylation.
Early diagnosis of RCC can be challenging. The classical clinical symptoms and signs of renal cancer are usually present only with late disease, when prognosis is poor; these symptoms - pain, palpable flank mass and hematuria - are present in only approximately $10 \%$ of patients [100]. The aim is to detect RCC early when the tumor is still confined, as this has a significant impact on long-term disease-free survival. Although an increasing number of RCCs are detected as incidental findings on abdominal imaging, distinguishing benign and malignant masses in such a situation can be difficult. However, DNA can be detected from cells sloughed from the tumor into urine or blood, and three studies [41-43] have successfully detected the presence of promoter methylation, by methylation-specific PCR, from DNA extracted from serum and urine of patients with RCC. Methylation of the Wnt antagonists SFRP1, SFRP2, SFRP4, SFRP 5, DKK3 and WIF1 was detected in tumor DNA in the serum of patients in whom those genes were methylated in their tumor. Moreover, the frequency of methylation detection in serum correlated significantly with increased grade and stage, suggesting that detection of these methylationspecific PCR products may be useful as markers of tumor progression [63]. Using a panel of previously identified RCC-specific methylated genes, two of these studies $[41,43]$ have found a strong correlation between tumor methylation and methylated DNA obtained from patient urine. Methylation was not found in control, age-matched urine samples. The panels of genes used in these studies included VHL, RASSF1, MGMT, GSTP1, p16INK4, p14ARF, APC and TIMP3. The specificity for genes such as $V H L$ and RASSF1, which are frequently methylated and believed to be inactivated at an early stage of tumor development, suggests that methylation-specific PCRbased hypermethylation panel arrays could have potential as an economically viable early detection screen for patients presenting non-specific symptoms and for distinguishing benign and malign renal masses. 
Only a few genes that might have potential as prognostic biomarkers have been analyzed in urine or blood from RCC patients. However, the tumor methylation status of several TSGs has been correlated with prognosis. Two independent studies $[63,64]$ have reported an inverse correlation between SFRP1 promoter methylation and patient survival (in vitro and in vivo assays both suggested that SFRP1 had tumor suppressing activity in RCC $[62,64])$. Methylation of COL14A1 and BNC1 was significantly associated with a poorer prognosis and this was a better prognostic indicator than tumor stage or grade [64]. JUP methylation was detected in a very high proportion of tumors tested (91\%) and was reported to be an independent indicator of disease progression and patient survival [101]. Similarly, a significant correlation between methylation of the bone morphogenetic protein antagonist GREM1 and tumor grade and stage and poor prognosis was reported [102], and methylation of TU3A was significantly associated with advanced tumor stage (later than stage T2) and poor survival [50]. The methylation status of several TSGs has been correlated with tumor pathological characteristics but not prognosis. HOXB13 methylation, for example, was correlated with tumor grade, stage, size and microvessel invasion [103], whereas $D K K 1$ methylation correlated with increased pathological grade [66] and $D K K 2$ methylation correlated with both increased stage and grade [65]. However, most of these studies require replication and, although RASSF1 methylation was reported to correlate with stage $[44,46]$ and grade [44], the largest study so far found no correlation with grade [39].

Clearly it is important that there should be further studies of potential methylated biomarkers in tumor tissue and urine and/or blood with the ultimate aim of producing a panel of biomarkers that will enable noninvasive detection, molecular staging and prediction of prognosis. As the number of potential methylated TSG biomarkers increases, it will be of great importance to assay these in a standardized manner in prospective studies to establish their clinical utility.

\section{Promoter methylation as a target for therapy}

The identification of frequently methylated RCC TSGs highlights critical pathways that could potentially be targeted for novel therapeutic interventions in RCC and other cancer types. In addition, there are less genespecific approaches to epigenetic therapy. Decitabine, the clinical form of the demethylating agent 5-aza-2'-deoxycytidine, has been investigated in several clinical trials for neoplasia, and promising responses have been reported in hematological malignancies (such as myelodysplastic syndrome $[18,104,105])$, although the response rates seem to be lower for common solid tumors. However, epigenetic therapy to alter cancer methylation or histone modification status is an area of increasing clinical trial activity. Clearly, strategies such as tumor methylation profiling, which could identify cancer patients most likely to respond to such therapies, would be a major advance.

\section{Future prospects}

Technological advances are accelerating the pace of methylation profiling for common human cancers. The advent of high-throughput hybridization-based assays can allow the methylation status of around 14,000 genes to be analyzed simultaneously (although only a few CpGs are interrogated for each gene) and strategies based on second generation massively parallel sequencing technologies will undoubtedly provide a more complete assessment of RCC epigenetics and elucidate novel RCC TSGs. One advantage of these approaches over the older 'candidate gene epigenetic status approach' is that the simultaneous analysis of many genes allows a better comparison of TSG methylation frequencies for specific genes and is likely to facilitate comparison between different studies. With increasing numbers of methylated TSGs in RCC identified, our knowledge of the molecular pathogenesis of RCC will increase and with it the potential for developing novel biomarkers and potential therapeutic interventions.

\section{Abbreviations}

cCRCC, clear cell renal cell carcinoma; PRCC, papillary RCC; RCC, renal cell carcinoma; TSG, tumor suppressor gene.

\section{Competing interests}

The authors declare that they have no competing interests.

\section{Authors' contributions}

Both authors contributed to manuscript preparation and editing.

\section{Author details}

'Renal Molecular Oncology Group, Medical and Molecular Genetics, School of Clinical and Experimental Medicine, College of Medical and Dental Sciences, University of Birmingham, Birmingham B15 2TT, UK. ${ }^{2}$ Centre for Rare Diseases and Personalised Medicine, University of Birmingham, Birmingham B15 2TT, UK. 'West Midlands Region Genetics Service, Birmingham Women's Hospital, Edgbaston, Birmingham B15 2TG, UK.

Published: 3 September 2010

\section{References}

1. Ferlay J, Autier P, Boniol M, Heanue M, Colombet M, Boyle P: Estimates of the cancer incidence and mortality in Europe in 2006. Ann Oncol 2007, 18:581-592.

2. Mancini V, Battaglia M, Ditonno P, Palazzo S, Lastilla G, Montironi R, Bettocchi C, Cavalcanti E, Ranieri E, Selvaggi FP: Current insights in renal cell cancer pathology. Urol Oncol 2008, 26:225-238.

3. Clifford SC, Prowse AH, Affara NA, Buys CH, Maher ER: Inactivation of the von Hippel-Lindau (VHL) tumour suppressor gene and allelic losses at chromosome arm $3 p$ in primary renal cell carcinoma: evidence for a VHL-independent pathway in clear cell renal tumourigenesis. Genes Chromosomes Cancer 1998, 22:200-209.

4. Foster $\mathrm{K}$, Crossey PA, Cairns P, Hetherington JW, Richards FM, Jones MH, Bentley E, Affara NA, Ferguson-Smith MA, Maher ER: Molecular genetic investigation of sporadic renal cell carcinoma: analysis of allele loss on chromosomes 3p, 5q, 11p, 17 and 22. Br J Cancer 1994, 69:230-234.

5. Herman JG, Latif F, Weng Y, Lerman MI, Zbar B, Liu S, Samid D, Duan DS, Gnarra JR, Linehan WM: Silencing of the VHL tumor-suppressor gene by 
DNA methylation in renal carcinoma. Proc Natl Acad Sci USA 1994, 91:9700-9704.

6. Latif F, Tory K, Gnarra J, Yao M, Duh FM, Orcutt ML, Stackhouse T, Kuzmin I, Modi W, Geil L: Identification of the von Hippel-Lindau disease tumor suppressor gene. Science 1993, 260:1317-1320.

7. Maxwell PH, Wiesener MS, Chang GW, Clifford SC, Vaux EC, Cockman ME, Wykoff CC, Pugh CW, Maher ER, Ratcliffe PJ: The tumour suppressor protein VHL targets hypoxia-inducible factors for oxygen-dependent proteolysis. Nature 1999, 399:271-275.

8. Maher ER, Yates JR, Ferguson-Smith MA: Statistical analysis of the two stage mutation model in von Hippel-Lindau disease, and in sporadic cerebellar haemangioblastoma and renal cell carcinoma. J Med Genet 1990, 27:311-314

9. Banks RE, Tirukonda P, Taylor C, Hornigold N, Astuti D, Cohen D, Maher ER, Stanley AJ, Harnden P, Joyce A, Knowles M, Selby PJ: Genetic and epigenetic analysis of von Hippel-Lindau (VHL) gene alterations and relationship with clinical variables in sporadic renal cancer. Cancer Res 2006, 66:2000-2011.

10. Catalogue of Somatic Mutations in Cancer [http://www.sanger.ac.uk/ genetics/CGP/cosmic/]

11. Bird A: DNA methylation patterns and epigenetic memory. Genes Dev 2002, 16:6-21

12. Nguyen CT, Gonzales FA, Jones PA: Altered chromatin structure associated with methylation-induced gene silencing in cancer cells: correlation of accessibility, methylation, MeCP2 binding and acetylation. Nucleic Acids Res 2001, 29:4598-4606

13. Fahrner JA, Equchi S, Herman JG, Baylin SB: Dependence of histone modifications and gene expression on DNA hypermethylation in cancer. Cancer Res 2002, 62:7213-7218.

14. Ballestar E, Paz MF, Valle L, Wei S, Fraga MF, Espada J, Cigudosa JC, Huang TH-M, Esteller M: Methyl-CpG binding proteins identify novel sites of epigenetic inactivation in human cancer. EMBO J 2003, 22:6335-6345.

15. Fraga MF, Ballestar E, Villar-Garea A, Boix-Chornet M, Espada J, Schotta G, Bonaldi T, Haydon C, Ropero S, Petrie K, lyer NG, Pérez-Rosado A, Calvo E, Lopez JA, Cano A, Calasanz MJ, Colomer D, Piris MA, Ahn N, Imhof A, Caldas C, Jenuwein T, Esteller M: Loss of acetylation at Lys16 and trimethylation at Lys 20 of histone $\mathrm{H} 4$ is a common hallmark of human cancer. Nat Genet 2005, 37:391-400.

16. Pruitt K, Zinn RL, Ohm JE, McGarvey KM, Kang S-HL, Watkins DN, Herman JG, Baylin SB: Inhibition of SIRT1 reactivates silenced cancer genes without loss of promoter DNA hypermethylation. PLOS Genet 2006, 2:e40.

17. Jones PA, Taylor SM: Cellular differentiation, cytidine analogs and DNA methylation. Cell 1980, 20:85-93.

18. Issa J-PJ, Kantarjian HM: Targeting DNA methylation. Clin Cancer Res 2009, 15:3938-3946.

19. Kikuchi R, Yagi S, Kusuhara H, Imai S, Sugiyama Y, Shiota K: Genome-wide analysis of epigenetic signatures for kidney-specific transporters. Kidney Int 2010, doi:10.1038/ki.2010.176.

20. Sørensen AL, Jacobsen BM, Reiner AH, Andersen IS, Collas P: Promoter DNA methylation patterns of differentiated cells are largely programmed at the progenitor stage. Mol Biol Cell 2010, 21:2066-2077.

21. Bodey B: Cancer-testis antigens: promising targets for antigen directed antineoplastic immunotherapy. Expert Opin Biol Ther 2002, 2:577-584.

22. Reik W, Lewis A: Co-evolution of X-chromosome inactivation and imprinting in mammals. Nat Rev Genet 2005, 6:403-410.

23. Herman JG, Baylin SB: Gene silencing in cancer in association with promoter hypermethylation. N Engl J Med 2003, 349:2042-2054

24. Feinberg AP, Tycko B: The history of cancer epigenetics. Nat Rev Cancer 2004, 4:143-153

25. Egger $G$, Liang $G$, Aparicio A, Jones PA: Epigenetics in human disease and prospects for epigenetic therapy. Nature 2004, 429:457-463.

26. Esteller M: Aberrant DNA methylation as a cancer-inducing mechanism. Annu Rev Pharmacol Toxicol 2005, 45:629-656.

27. Nakagawa Y, Uemura H, Shimizu K, Cho M, Yoshikawa M, Hirao Y, Yoshikawa K: [The role of MN/CA IX antigen in carcinogenesis and metastasis of renal cell carcinoma]. Hinyokika Kiyo 2001, 47:809-814.

28. Esteller M, Catasus L, Matias-Guiu X, Mutter GL, Prat J, Baylin SB, Herman JG: $\mathrm{hMLH} 1$ promoter hypermethylation is an early event in human endometrial tumorigenesis. Am J Pathol 1999, 155:1767-1772.

29. Prowse AH, Webster AR, Richards FM, Richard S, Olschwang S, Resche F, Affara NA, Maher ER: Somatic inactivation of the VHL gene in Von Hippel-Lindau disease tumors. Am J Hum Genet 1997, 60:765-771.

30. Ongenaert M, van Neste L, De Meyer T, Menschaert G, Bekaert S, Van Criekinge W: PubMeth: a cancer methylation database combining textmining and expert annotation. Nucleic Acids Res 2008, 36:D842-D846.

31. Kok K, Naylor SL, Buys CH: Deletions of the short arm of chromosome 3 in solid tumors and the search for suppressor genes. Adv Cancer Res 1997, 71:27-92.

32. Kovacs $\mathrm{G}$, Frisch S: Clonal chromosome abnormalities in tumor cells from patients with sporadic renal cell carcinomas. Cancer Res 1989, 49:651-659.

33. Beroukhim R, Brunet J-P, Di Napoli A, Mertz KD, Seeley A, Pires MM, Linhart D, Worrell RA, Moch H, Rubin MA, Sellers WR, Meyerson M, Linehan WM, Kaelin WG Jr, Signoretti S: Patterns of gene expression and copy-number alterations in von-Hippel Lindau disease-associated and sporadic clear cell carcinoma of the kidney. Cancer Res 2009, 69:4674-4681.

34. Young AC, Craven RA, Cohen D, Taylor C, Booth C, Harnden P, Cairns DA Astuti D, Gregory W, Maher ER, Knowles MA, Joyce A, Selby PJ, Banks RE: Analysis of $\mathrm{VHL}$ gene alterations and their relationship to clinical parameters in sporadic conventional renal cell carcinoma. Clin Cancer Res 2009, 15:7582-7592.

35. Dulaimi E, Ibanez de Caceres I, Uzzo RG, Al-Saleem T, Greenberg RE, Polascik TJ, Babb JS, Grizzle WE, Cairns P: Promoter hypermethylation profile of kidney cancer. Clin Cancer Res 2004, 10:3972-3979.

36. Hori Y, Oda Y, Kiyoshima K, Yamada Y, Nakashima Y, Naito S, Tsuneyoshi M: Oxidative stress and DNA hypermethylation status in renal cell carcinoma arising in patients on dialysis. J Patho/ 2007, 212:218-226.

37. Nickerson ML, Jaeger E, Shi Y, Durocher JA, Mahurkar S, Zaridze D, Matveev V, Janout V, Kollarova H, Bencko V, Navratilova M, Szeszenia-Dabrowska N, Mates D, Mukeria A, Holcatova I, Schmidt LS, Toro JR, Karami S, Hung R, Gerard GF, Linehan WM, Merino M, Zbar B, Boffetta P, Brennan P, Rothman N, Chow WH, Waldman FM, Moore LE: Improved identification of von Hippel-Lindau gene alterations in clear cell renal tumors. Clin Cancer Res 2008, 14:4726-4734.

38. Hesson LB, Cooper WN, Latif F: Evaluation of the 3p21.3 tumour-suppressor gene cluster. Oncogene 2007, 26:7283-7301.

39. Morrissey C, Martinez A, Zatyka M, Agathanggelou A, Honorio S, Astuti D, Morgan NV, Moch H, Richards FM, Kishida T, Yao M, Schraml P, Latif F, Maher ER: Epigenetic inactivation of the RASSF1A 3p21.3 tumor suppressor gene in both clear cell and papillary renal cell carcinoma. Cancer Res 2001, 61:7277-7281.

40. Lusher ME, Lindsey JC, Latif F, Pearson ADJ, Ellison DW, Clifford SC: Biallelic epigenetic inactivation of the RASSF1A tumor suppressor gene in medulloblastoma development. Cancer Res 2002, 62:5906-5911.

41. Battagli C, Uzzo RG, Dulaimi E, Ibanez de Caceres I, Krassenstein R, Al-Saleem T, Greenberg RE, Cairns P: Promoter hypermethylation of tumor suppressor genes in urine from kidney cancer patients. Cancer Res 2003, 63:8695-8699.

42. Onay H, Pehlivan S, Koyuncuoglu M, Kirkali Z, Ozkinay F: Multigene methylation analysis of conventional renal cell carcinoma. Urol Int 2009, 83:107-112.

43. Hoque MO, Begum S, Topaloglu O, Jeronimo C, Mambo E, Westra WH, Califano JA, Sidransky D: Quantitative detection of promoter hypermethylation of multiple genes in the tumor, urine, and serum DNA of patients with renal cancer. Cancer Res 2004, 64:5511-5517.

44. Costa VL, Henrique R, Ribeiro FR, Pinto M, Oliveira J, Lobo F, Teixeira MR, Jerónimo C: Quantitative promoter methylation analysis of multiple cancer-related genes in renal cell tumors. BMC Cancer 2007, 7:133.

45. Dreijerink K, Braga E, Kuzmin I, Geil L, Duh FM, Angeloni D, Zbar B, Lerman MI, Stanbridge EJ, Minna JD, Protopopov A, Li J, Kashuba V, Klein G, Zabarovsky ER: The candidate tumor suppressor gene, RASSF1A, from human chromosome 3p21.3 is involved in kidney tumorigenesis. Proc Natl Acad Sci USA 2001, 98:7504-7509.

46. Gonzalgo ML, Yegnasubramanian S, Yan G, Rogers CG, Nicol TL, Nelson WG Pavlovich CP: Molecular profiling and classification of sporadic renal cell carcinoma by quantitative methylation analysis. Clin Cancer Res 2004, 10:7276-7283

47. Yoon JH, Dammann R, Pfeifer GP: Hypermethylation of the CpG island of the RASSF1A gene in ovarian and renal cell carcinomas. Int J Cancer 2001, 94:212-217.

48. Vanaja DK, Ballman KV, Morlan BW, Cheville JC, Neumann RM, Lieber MM, Tindall DJ, Young CYF: PDLIM4 repression by hypermethylation as a potential biomarker for prostate cancer. Clin Cancer Res 2006, 12:1128-1136.

49. van den Boom J, Wolter M, Blaschke B, Knobbe CB, Reifenberger G: Identification of novel genes associated with astrocytoma progression 
using suppression subtractive hybridization and real-time reverse transcription-polymerase chain reaction. Int J Cancer 2006, 119:2330-2338.

50. Awakura Y, Nakamura E, Ito N, Kamoto T, Ogawa O: Methylation-associated silencing of TU3A in human cancers. Int J Oncol 2008, 33:893-899.

51. Druck T, Hadaczek P, Fu TB, Ohta M, Siprashvili Z, Baffa R, Negrini M, Kastury K, Veronese ML, Rosen D, Rothstein J, McCue P, Cotticelli MG, Inoue H, Croce CM, Huebner K: Structure and expression of the human FHIT gene in normal and tumor cells. Cancer Res 1997, 57:504-512.

52. Sozzi G, Pastorino U, Moiraghi L, Tagliabue E, Pezzella F, Ghirelli C, Tornielli S, Sard L, Huebner K, Pierotti MA, Croce CM, Pilotti S: Loss of FHIT function in lung cancer and preinvasive bronchial lesions. Cancer Res 1998, 58:5032-5037.

53. Dumon KR, Ishii H, Fong LY, Zanesi N, Fidanza V, Mancini R, Vecchione A, Baffa R, Trapasso F, During MJ, Huebner K, Croce CM: FHIT gene therapy prevents tumor development in Fhit-deficient mice. Proc Natl Acad Sci USA 2001, 98:3346-3351.

54. Kvasha S, Gordiyuk V, Kondratov A, Ugryn D, Zgonnyk YM, Rynditch AV, Vozianov AF: Hypermethylation of the $5^{\prime} \mathrm{CpG}$ island of the FHIT gene in clear cell renal carcinomas. Cancer Lett 2008, 265:250-257.

55. Morris MR, Hesson LB, Wagner KJ, Morgan NV, Astuti D, Lees RD, Cooper WN, Lee J, Gentle D, Macdonald F, Kishida T, Grundy R, Yao M, Latif F, Maher ER: Multigene methylation analysis of Wilms' tumour and adult renal cell carcinoma. Oncogene 2003, 22:6794-6801.

56. Vincan E: Frizzled/WNT signalling: the insidious promoter of tumour growth and progression. Front Biosci 2004, 9:1023-1034

57. Widelitz R: Wnt signaling through canonical and non-canonical pathways: recent progress. Growth Factors 2005, 23:111-116.

58. Kawano Y, Kypta R: Secreted antagonists of the Wnt signalling pathway. J Cell Sci 2003, 116:2627-2634

59. Niehrs C: Function and biological roles of the Dickkopf family of Wnt modulators. Oncogene 2006, 25:7469-7481.

60. Awakura Y, Nakamura E, Ito N, Kamoto T, Ogawa O: Methylation-associated silencing of SFRP1 in renal cell carcinoma. Oncol Rep 2008, 20:1257-1263.

61. Dahl E, Wiesmann F, Woenckhaus M, Stoehr R, Wild PJ, Veeck J, Knüchel R, Klopocki E, Sauter G, Simon R, Wieland WF, Walter B, Denzinger S, Hartmann A, Hammerschmied CG: Frequent loss of SFRP1 expression in multiple human solid tumours: association with aberrant promoter methylation in renal cell carcinoma. Oncogene 2007, 26:5680-5691.

62. Gumz ML, Zou H, Kreinest PA, Childs AC, Belmonte LS, LeGrand SN, Wu KJ Luxon BA, Sinha M, Parker AS, Sun LZ, Ahlquist DA, Wood CG, Copland JA: Secreted frizzled-related protein 1 loss contributes to tumor phenotype of clear cell renal cell carcinoma. Clin Cancer Res 2007, 13:4740-4749.

63. Urakami S, Shiina H, Enokida H, Hirata H, Kawamoto K, Kawakami T, Kikuno N, Tanaka Y, Majid S, Nakagawa M, Igawa M, Dahiya R: Wnt antagonist family genes as biomarkers for diagnosis, staging, and prognosis of renal cell carcinoma using tumor and serum DNA. Clin Cancer Res 2006, 12:6989-6997.

64. Morris MR, Ricketts C, Gentle D, Abdulrahman M, Clarke N, Brown M, Kishida T, Yao M, Latif F, Maher ER: Identification of candidate tumour suppressor genes frequently methylated in renal cell carcinoma. Oncogene 2010, 29:2104-2117.

65. Hirata H, Hinoda Y, Nakajima K, Kawamoto K, Kikuno N, Kawakami K, Yamamura S, Ueno K, Majid S, Saini S, Ishii N, Dahiya R: Wnt antagonist gene DKK2 is epigenetically silenced and inhibits renal cancer progression through apoptotic and cell cycle pathways. Clin Cancer Res 2009, 15:5678-5687.

66. Hirata H, Hinoda Y, Nakajima K, Kawamoto K, Kikuno N, Ueno K, Yamamura S, Zaman MS, Khatri G, Chen Y,Saini S, Majid S, Deng G, Ishii N, Dahiya R: Wnt antagonist DKK1 acts as a tumor suppressor gene that induces apoptosis and inhibits proliferation in human renal cell carcinoma. Int J Cancer 2010, doi:10.1002/ijc.25507.

67. Saini S, Liu J, Yamamura S, Majid S, Kawakami K, Hirata H, Dahiya R: Functional significance of secreted Frizzled-related protein 1 in metastatic renal cell carcinomas. Cancer Res 2009, 69:6815-6822.

68. Chen J, Lui W-O, Vos MD, Clark GJ, Takahashi M, Schoumans J, Khoo SK, Petillo D, Lavery T, Sugimura J, Astuti D, Zhang C, Kagawa S, Maher ER, Larsson C, Alberts AS, Kanayama HO, Teh BT: The $t(1 ; 3)$ breakpoint-spanning genes LSAMP and NORE1 are involved in clear cell renal cell carcinomas. Cancer Cell 2003, 4:405-413.

69. Schmidt L, Junker K, Nakaigawa N, Kinjerski T, Weirich G, Miller M, Lubensky I, Neumann HP, Brauch H, Decker J, Vocke C, Brown JA, Jenkins R, Richard S,
Bergerheim U, Gerrard B, Dean M, Linehan WM, Zbar B: Novel mutations of the MET proto-oncogene in papillary renal carcinomas. Oncogene 1999, 18:2343-2350

70. Schmidt L, Duh FM, Chen F, Kishida T, Glenn G, Choyke P, Scherer SW, Zhuang Z, Lubensky I, Dean M, Allikmets R, Chidambaram A, Bergerheim UR, Feltis JT, Casadevall C, Zamarron A, Bernues M, Richard S, Lips CJ, Walther MM, Tsui LC, Geil L, Orcutt ML, Stackhouse T, Lipan J, Slife L, Brauch H, Decker J, Niehans G, Hughson MD, et al:: Germline and somatic mutations in the tyrosine kinase domain of the MET proto-oncogene in papillary renal carcinomas. Nat Genet 1997, 16:68-73

71. Morris MR, Gentle D, Abdulrahman M, Maina EN, Gupta K, Banks RE, Wiesener MS, Kishida T, Yao M, Teh B, Latif F, Maher ER: Tumor suppressor activity and epigenetic inactivation of hepatocyte growth factor activator inhibitor type 2/SPINT2 in papillary and clear cell renal cell carcinoma. Cancer Res 2005, 65:4598-4606.

72. Chitalia VC, Foy RL, Bachschmid MM, Zeng L, Panchenko MV, Zhou MI, Bharti A, Seldin DC, Lecker SH, Dominguez I, Cohen HT: Jade-1 inhibits Wnt signalling by ubiquitylating beta-catenin and mediates Wnt pathway inhibition by pVHL. Nat Cell Biol 2008, 10:1208-1216.

73. Zatyka M, da Silva NF, Clifford SC, Morris MR, Wiesener MS, Eckardt K-U, Houlston RS, Richards FM, Latif F, Maher ER: Identification of cyclin D1 and other novel targets for the von Hippel-Lindau tumor suppressor gene by expression array analysis and investigation of cyclin D1 genotype as a modifier in von Hippel-Lindau disease. Cancer Res 2002, 62:3803-3811.

74. Qi H, Ohh M: The von Hippel-Lindau tumor suppressor protein sensitizes renal cell carcinoma cells to tumor necrosis factor-induced cytotoxicity by suppressing the nuclear factor-kappaB-dependent antiapoptotic pathway. Cancer Res 2003, 63:7076-7080

75. Genetos DC, Toupadakis CA, Raheja LF, Wong A, Papanicolaou SE, Fyhrie DP Loots GG, Yellowley CE: Hypoxia decreases sclerostin expression and increases Wnt signaling in osteoblasts. J Cell Biochem 2010, 110:457-467.

76. Roe J-S, Youn H-D: The positive regulation of $\mathrm{p} 53$ by the tumor suppressor VHL. Cell Cycle 2006, 5:2054-2056.

77. Bishop T, Lau KW, Epstein ACR, Kim SK, Jiang M, O'Rourke D, Pugh CW, Gleadle JM, Taylor MS, Hodgkin J, Ratcliffe PJ: Genetic analysis of pathways regulated by the von Hippel-Lindau tumor suppressor in Caenorhabditis elegans. PLOS Bio/ 2004, 2:e289.

78. Kajimura S, Aida K, Duan C: Understanding hypoxia-induced gene expression in early development: in vitro and in vivo analysis of hypoxiainducible factor 1-regulated zebra fish insulin-like growth factor binding protein 1 gene expression. Mol Cell Biol 2006, 26:1142-1155.

79. Slomiany MG, Rosenzweig SA: IGF-1-induced VEGF and IGFBP-3 secretion correlates with increased HIF-1 alpha expression and activity in retinal pigment epithelial cell line D407. Invest Ophthalmol Vis Sci 2004, 45:2838-2847.

80. Yang S, Kim J, Ryu J-H, Oh H, Chun C-H, Kim BJ, Min BH, Chun J-S: Hypoxiainducible factor-2alpha is a catabolic regulator of osteoarthritic cartilage destruction. Nat Med 2010, 16:687-693.

81. Dalgliesh GL, Furge K, Greenman C, Chen L, Bignell G, Butler A, Davies H, Edkins S, Hardy C, Latimer C, Teague J, Andrews J, Barthorpe S, Beare D, Buck G, Campbell PJ, Forbes S, Jia M, Jones D, Knott H, Kok CY, Lau KW, Leroy C, Lin ML, McBride DJ, Maddison M, Maguire S, McLay K, Menzies A, Mironenko T, et al:: Systematic sequencing of renal carcinoma reveals inactivation of histone modifying genes. Nature 2010, 463:360-363.

82. Sanz-Casla MT, Maestro ML, del Barco V, Zanna I, Moreno J, Vidaurreta M, Almansa I, Fernández C, Blanco J, Maestro C, Resel L: Loss of heterozygosity and methylation of p16 in renal cell carcinoma. Urol Res 2003, 31:159-162.

83. Tong WG, Wierda WG, Lin E, Kuang SQ, Bekele BN, Estrov Z, Wei Y, Yang H, Keating MJ, Garcia-Manero G: Genome-wide DNA methylation profiling of chronic lymphocytic leukemia allows identification of epigenetically repressed molecular pathways with clinical impact. Epigenetics 2010, 5:499-508

84. Boumber YA, Kondo Y, Chen X, Shen L, Gharibyan V, Konishi K, Estey E, Kantarjian H, Garcia-Manero G, Issa J-PJ: RIL, a LIM gene on 5q31, is silenced by methylation in cancer and sensitizes cancer cells to apoptosis. Cancer Res 2007, 67:1997-2005

85. Tellez CS, Shen L, Estécio MRH, Jelinek J, Gershenwald JE, Issa J-PJ: CpG island methylation profiling in human melanoma cell lines. Melanoma Res 2009, 19:146-155.

86. Veena MS, Lee G, Keppler D, Mendonca MS, Redpath JL, Stanbridge EJ, Wilczynski SP, Srivatsan ES: Inactivation of the cystatin E/M tumor 
suppressor gene in cervical cancer. Genes Chromosomes Cancer 2008, 47:740-754.

87. Rivenbark AG, Livasy CA, Boyd CE, Keppler D, Coleman WB: Methylationdependent silencing of CST6 in primary human breast tumors and metastatic lesions. Exp Mol Pathol 2007, 83:188-197.

88. Dallol A, Krex D, Hesson L, Eng C, Maher ER, Latif F: Frequent epigenetic inactivation of the SLIT2 gene in gliomas. Oncogene 2003, 22:4611-4616.

89. Dunwell TL, Dickinson RE, Stankovic T, Dallol A, Weston V, Austen B, Catchpoole $D$, Maher ER, Latif F: Frequent epigenetic inactivation of the SLIT2 gene in chronic and acute lymphocytic leukemia. Epigenetics 2009, 4:265-269.

90. Hanafusa T, Yumoto Y, Nouso K, Nakatsukasa H, Onishi T, Fujikawa T, Taniyama M, Nakamura S, Uemura M, Takuma Y, Yumoto E, Higashi T, Tsuji T: Reduced expression of insulin-like growth factor binding protein-3 and its promoter hypermethylation in human hepatocellular carcinoma. Cancer Lett 2002, 176:149-158.

91. Wiley A, Katsaros D, Fracchioli S, Yu H: Methylation of the insulin-like growth factor binding protein-3 gene and prognosis of epithelial ovarian cancer. Int J Gynecol Cancer 2006, 16:210-218.

92. Kongkham PN, Northcott PA, Ra YS, Nakahara Y, Mainprize TG, Croul SE, Smith CA, Taylor MD, Rutka JT: An epigenetic genome-wide screen identifies SPINT2 as a novel tumor suppressor gene in pediatric medulloblastoma. Cancer Res 2008, 68:9945-9953.

93. Tung EK-K, Wong C-M, Yau T-O, Lee JM-F, Ching Y-P, Ng IO-L: HAI-2 is epigenetically downregulated in human hepatocellular carcinoma, and its Kunitz domain type 1 is critical for anti-invasive functions. Int J Cancer 2009, 124:1811-1819.

94. Dong W, Chen X, Xie J, Sun P, Wu Y: Epigenetic inactivation and tumor suppressor activity of HAI-2/SPINT2 in gastric cancer. Int J Cancer 2010, 127:1526-1534.

95. Irizarry RA, Ladd-Acosta C, Wen B, Wu Z, Montano C, Onyango P, Cui H, Gabo K, Rongione M, Webster M, Ji H, Potash JB, Sabunciyan S, Feinberg AP: The human colon cancer methylome shows similar hypo- and hypermethylation at conserved tissue-specific CpG island shores. Nat Genet 2009, 41:178-186.

96. Weisenberger DJ, Siegmund KD, Campan M, Young J, Long TI, Faasse MA, Kang GH, Widschwendter M, Weener D, Buchanan D, Koh H, Simms L, Barker M, Leggett B, Levine J, Kim M, French AJ, Thibodeau SN, Jass J, Haile R, Laird PW: CpG island methylator phenotype underlies sporadic microsatellite instability and is tightly associated with BRAF mutation in colorectal cancer. Nat Genet 2006, 38:787-793.

97. McRonald FE, Morris MR, Gentle D, Winchester L, Baban D, Ragoussis J, Clarke NW, Brown MD, Kishida T, Yao M, Latif F, Maher ER: CpG methylation profiling in VHL related and VHL unrelated renal cell carcinoma. Mol Cancer 2009, 8:31.

98. van Haaften G, Dalgliesh GL, Davies H, Chen L, Bignell G, Greenman C, Edkins S, Hardy C, O'Meara S, Teague J, Butler A, Hinton J, Latimer C, Andrews J, Barthorpe S, Beare D, Buck G, Campbell PJ, Cole J, Forbes S, Jia M, Jones D, Kok CY, Leroy C, Lin ML, McBride DJ, Maddison M, Maquire S, McLay K, Menzies A, et al: Somatic mutations of the histone H3K27 demethylase gene UTX in human cancer. Nat Genet 2009, 41:521-523.

99. Cairns P: Gene methylation and early detection of genitourinary cancer: the road ahead. Nat Rev Cancer 2007, 7:531-543.

100. Baylin SB, Herman JG, Graff JR, Vertino PM, Issa JP: Alterations in DNA methylation: a fundamental aspect of neoplasia. Adv Cancer Res 1998 72:141-196

101. Breault JE, Shiina $H$, Igawa M, Ribeiro-Filho LA, Deguchi M, Enokida $H$, Urakami S, Terashima M, Nakagawa M, Kane CJ, Carroll PR, Dahiya R: Methylation of the gamma-catenin gene is associated with poor prognosis of renal cell carcinoma. Clin Cancer Res 2005, 11:557-564.

102. van Vlodrop IJH, Baldewijns MML, Smits KM, Schouten L, van Neste L, Van Criekinge W, van Poppel H, Lerut E, Schuebel KE, Ahuja N, Herman JG, de Bruïne AP, van Engeland M: Prognostic significance of Gremlin1 (GREM1) promoter CpG island hypermethylation in clear cell renal cell carcinoma. Am J Pathol 2010, 176:575-584.

103. Okuda H, Toyota M, Ishida W, Furihata M, Tsuchiya M, Kamada M, Tokino T Shuin T: Epigenetic inactivation of the candidate tumor suppressor gene HOXB13 in human renal cell carcinoma. Oncogene 2006, 25:1733-1742.

104. Silverman LR, Demakos EP, Peterson BL, Kornblith AB, Holland JC, OdchimarReissig R, Stone RM, Nelson D, Powell BL, DeCastro CM, Ellerton J, Larson RA, Schiffer CA, Holland JF: Randomized controlled trial of azacitidine in patients with the myelodysplastic syndrome: a study of the cancer and leukemia group B. J Clin Oncol 2002, 20:2429-2440.
105. Oki Y, Jelinek J, Shen L, Kantarjian HM, Issa JP: Induction of hypomethylation and molecular response after decitabine therapy in patients with chronic myelomonocytic leukemia. Blood 2008, 111:2382-2384.

106. Ibanez de Caceres I, Dulaimi E, Hoffman AM, Al-Saleem T, Uzzo RG, Cairns P: Identification of novel target genes by an epigenetic reactivation screen of renal cancer. Cancer Res 2006, 66:5021-5028.

107. Christoph F, Weikert S, Kempkensteffen C, Krause H, Schostak M, Köllermann J, Miller K, Schrader M: Promoter hypermethylation profile of kidney cancer with new proapoptotic p53 target genes and clinical implications. Clin Cancer Res 2006, 12:5040-5046.

108. Majid S, Dar AA, Ahmad AE, Hirata H, Kawakami K, Shahryari V, Saini S, Tanaka Y, Dahiya AV, Khatri G, Dahiya R: BTG3 tumor suppressor gene promoter demethylation, histone modification and cell cycle arrest by genistein in renal cancer. Carcinogenesis 2009, 30:662-670.

109. Morris MR, Gentle D, Abdulrahman M, Clarke N, Brown M, Kishida T, Yao M, Teh BT, Latif F, Maher ER: Functional epigenomics approach to identify methylated candidate tumour suppressor genes in renal cell carcinoma. Br J Cancer 2008, 98:496-501.

110. Yamada D, Kikuchi S, Williams YN, Sakurai-Yageta M, Masuda M, Maruyama T, Tomita K, Gutmann DH, Kakizoe T, Kitamura T, Kanai Y, Murakami Y: Promoter hypermethylation of the potential tumor suppressor DAL-1/4.1B gene in renal clear cell carcinoma. Int J Cancer 2006, 118:916-923.

111. Christoph F, Kempkensteffen C, Weikert S, Köllermann J, Krause H, Miller K, Schostak M, Schrader M: Methylation of tumour suppressor genes APAF-1 and DAPK-1 and in vitro effects of demethylating agents in bladder and kidney cancer. Br J Cancer 2006, 95:1701-1707.

112. Zhang Q, Ying J, Zhang K, Li H, Ng KM, Zhao Y, He Q, Yang X, Xin D, Liao S-K, Tao Q, Jin J: Aberrant methylation of the 8p22 tumor suppressor gene DLC1 in renal cell carcinoma. Cancer Lett 2007, 249:220-226.

113. Khoo SK, Kahnoski K, Sugimura J, Petillo D, Chen J, Shockley K, Ludlow J, Knapp R, Giraud S, Richard S, Nordenskjöld M, Teh BT: Inactivation of BHD in sporadic renal tumors. Cancer Res 2003, 63:4583-4587.

114. da Silva NF, Gentle D, Hesson LB, Morton DG, Latif F, Maher ER: Analysis of the Birt-Hogg-Dubé (BHD) tumour suppressor gene in sporadic renal cell carcinoma and colorectal cancer. J Med Genet 2003, 40:820-824.

115. Gad S, Lefèvre SH, Khoo SK, Giraud S, Vieillefond A, Vasiliu V, Ferlicot S, Molinié V, Denoux Y, Thiounn N, Chrétien Y, Méjean A, Zerbib M, Benoît G, Hervé JM, Allègre G, Bressac-de Paillerets B, Teh BT, Richard S: Mutations in BHD and TP53 genes, but not in HNF1beta gene, in a large series of sporadic chromophobe renal cell carcinoma. Br J Cancer 2007, 96:336-340.

116. Seliger B, Handke D, Schabel E, Bukur J, Lichtenfels R, Dammann R: Epigenetic control of the ubiquitin carboxyl terminal hydrolase 1 in renal cell carcinoma. J Trans/ Med 2009, 7:90

117. Dallol A, Forgacs E, Martinez A, Sekido Y, Walker R, Kishida T, Rabbitts P, Maher ER, Minna JD, Latif F: Tumour specific promoter region methylation of the human homologue of the Drosophila Roundabout gene DUTT1 (ROBO1) in human cancers. Oncogene 2002, 21:3020-3028.

118. Astuti D, Da Silva NF, Dallol A, Gentle D, Martinsson T, Kogner P, Grundy R Kishida T, Yao M, Latif F, Maher ER: SLIT2 promoter methylation analysis in neuroblastoma, Wilms' tumour and renal cell carcinoma. Br J Cancer 2004, 90:515-521.

119. Bachman KE, Herman JG, Corn PG, Merlo A, Costello JF, Cavenee WK, Baylin SB, Graff JR: Methylation-associated silencing of the tissue inhibitor of metalloproteinase-3 gene suggest a suppressor role in kidney, brain, and other human cancers. Cancer Res 1999, 59:798-802.

120. Kempkensteffen C, Hinz S, Schrader M, Christoph F, Magheli A, Krause H, Schostak M, Miller K, Weikert S: Gene expression and promoter methylation of the XIAP-associated Factor 1 in renal cell carcinomas: correlations with pathology and outcome. Cancer Lett 2007, 254:227-235

121. Lee M-G, Huh J-S, Chung S-K, Lee J-H, Byun D-S, Ryu B-K, Kang M-J, Chae K-S, Lee S-J, Lee C-H, Kim Jl, Chang SG, Chi SG: Promoter CpG hypermethylation and downregulation of XAF1 expression in human urogenital malignancies: implication for attenuated $\mathrm{p} 53$ response to apoptotic stresses. Oncogene 2006, 25:5807-5822.

\section{doi:10.1186/gm180}

Cite this article as: Morris MR, Maher ER: Epigenetics of renal cell carcinoma: the path towards new diagnostics and therapeutics. Genome Medicine 2010, 2:59. 